\title{
Parturition dates in wild Eurasian lynx: evidence of a second oestrus?
}

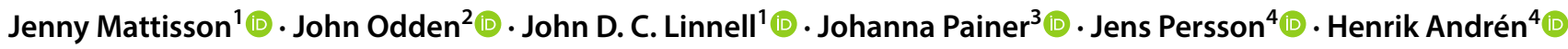

Received: 31 January 2020 / Accepted: 8 May 2020 / Published online: 8 June 2020

(c) The Author(s) 2020

\begin{abstract}
Understanding reproductive physiology of a species is important to assess their potential to respond to environmental variation and perturbation of their social system during the mating or pre-mating seasons. We report 175 parturition dates from wild Eurasian lynx (Lynx lynx) in Scandinavia. Most lynx birth dates were highly synchronised around a mean of 30th May ( $\mathrm{SD}=9$ days) with 173 of the 175 births ranging from May 2nd to June 30th. We detected two very late births on July 29th and August 15th in the absence of any indication that the females had given birth and lost a litter earlier in the year. We propose that these represent evidence of a second oestrus which is highly unusual in lynx because of their unique reproductive physiology. The rarity of these late season births has implications for lynx demography and social organisation.
\end{abstract}

Keywords Lynx lynx $\cdot$ Reproduction $\cdot$ Parturition date $\cdot$ Conservation

Eurasian lynx (Lynx lynx), the largest species in the Lynx genus, is a solitary felid inhabiting the boreal forest of Eurasia (Chapron et al. 2014). Eurasian lynx become sexually mature at two years of age (Axner et al. 2009) but not all 2-year olds manage to breed successfully (Nilsen et al. 2012b). In Scandinavia, lynx mate in March-April and after a gestation length of 66-70 days (Painer et al. 2014) they give birth to $1-4$ kittens, 2 being the most common litter size (Gaillard et al. 2014). The kittens stay with their mother until they are between 8 and 11 months old (Samelius et al. 2012). In contrast to most felid species (e.g. Jansen and Jenks 2012; Balme et al. 2013), lynx are strict seasonal breeders (Henriksen et al. 2005), reproducing only once a year and normally with only a single ovulatory cycle (Painer et al. 2014). Female lynx display a unique physiology of persistent

Handling editor: Yoshiyuki Henning.

Jenny Mattisson

jenny.mattisson@nina.no

1 Norwegian Institute for Nature Research (NINA), 7485 Trondheim, Norway

2 Norwegian Institute for Nature Research (NINA), 0349 Oslo, Norway

3 Department of Interdisciplinary Life Sciences, University of Veterinary Medicine Vienna, 1160 Vienna, Austria

4 Grimsö Wildlife Research Station, Department of Ecology, Swedish University of Agricultural Sciences, 73091 Riddarhyttan, Sweden corpora lutea, which produce elevated serum progesterone levels during the non-mating season which normally hinders an oestrus onset later in the season (Painer et al. 2014). This results in a highly synchronised birth season, with only single anecdotal published incidences of late births in captive (Henriksen et al. 2005) and wild (Breitenmoser-Würsten et al. 2007) lynx.

Reproduction is costly for female lynx (Nilsen et al. 2010) and breeding success increases with the availability of food resources and age (Nilsen et al. 2012b; Walton et al. 2017). The timing of birth is thus most likely crucial to match weaning with a period rich in resources and to minimise thermal stress on neonates, although the summer resource pulse is not so narrow as to fully explain why lynx do not more often show a second oestrus cycle. An alternative explanation is that this is an adaptation to remove the incentive for males to commit infanticide which is very common in other felids that lack clear seasonal birth cycles (e.g. Logan and Sweanor 2001; Balme and Hunter 2013) but is almost absent in Lynx. As such, the adaptive nature of their unique reproductive physiology is not totally clear, but it can be hoped that greater insights can emerge as more data from a diversity of situations becomes available.

In this study we present data on parturition date from 198 reproductive events by 96 radio-collared lynx females, spanning a large geographical range within Norway and Sweden $(55.69 \mathrm{~N}-70.37 \mathrm{~N})$ with the goal of looking for 
out-of-season births which would be evidence of a second oestrus in the wild.

Lynx were equipped with VHF- or GPS-collars following standard handling protocols approved by the Swedish Animal Ethics Committee and the Norwegian Experimental Animal Ethics Committee. Data were collected from 1996 to 2015 from study sites throughout Scandinavia. Details on lynx capture can be found elsewhere (Andrén et al. 2006; Mattisson et al. 2011; Arnemo et al. 2012; Odden et al. 2013).

Female lynx adopt a central place foraging behaviour centred on a natal lair for the first weeks of the kittens' lives (Schmidt 1998). This behaviour enables the den location, and the parturition date, to be determined by examination of high resolution GPS-location data or intensive monitoring by VHF. All reproductive events were confirmed by a visit to the natal lair when kittens where 1-6 weeks old, or by observing 1 or more kittens with the female in the following winter (only for some few GPS-collared individuals). We assume that the kittens were born on the first day the female started using the natal lair and reduced movements to a minimum. For some VHF-collared individuals in Sweden, the first day of denning could not be determined from movement data. Birth date for these individuals was estimated from a model based on weights of other kittens with known birth date, measured during natal lair control (1-6 weeks of age) (Fig. 1).

Lynx parturition dates were observed as early as May 2nd and as late as August 15th but were centred around May 30th ( $\mathrm{SD}=9$ days; Fig. 2). The two latest parturition dates,

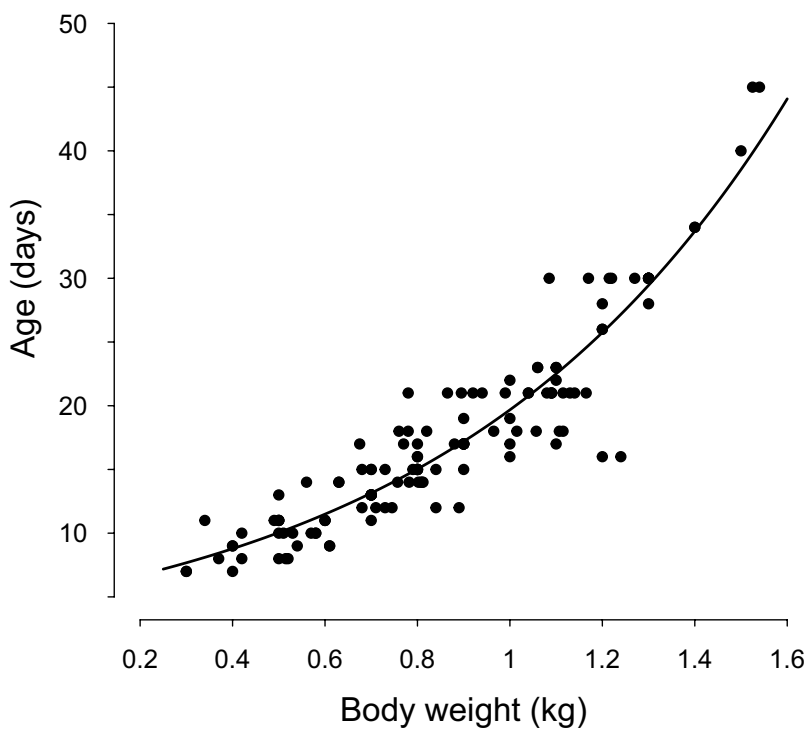

Fig. 1 The relationship between age (days) and body weight $(\mathrm{kg})$ of captured kittens with known parturition date used to estimate date of birth when body weight is known $(\mathrm{Age}=\exp (1.64+1.34 \times$ body weight); $R^{2}=0.72, p<0.0001, n=132$ )

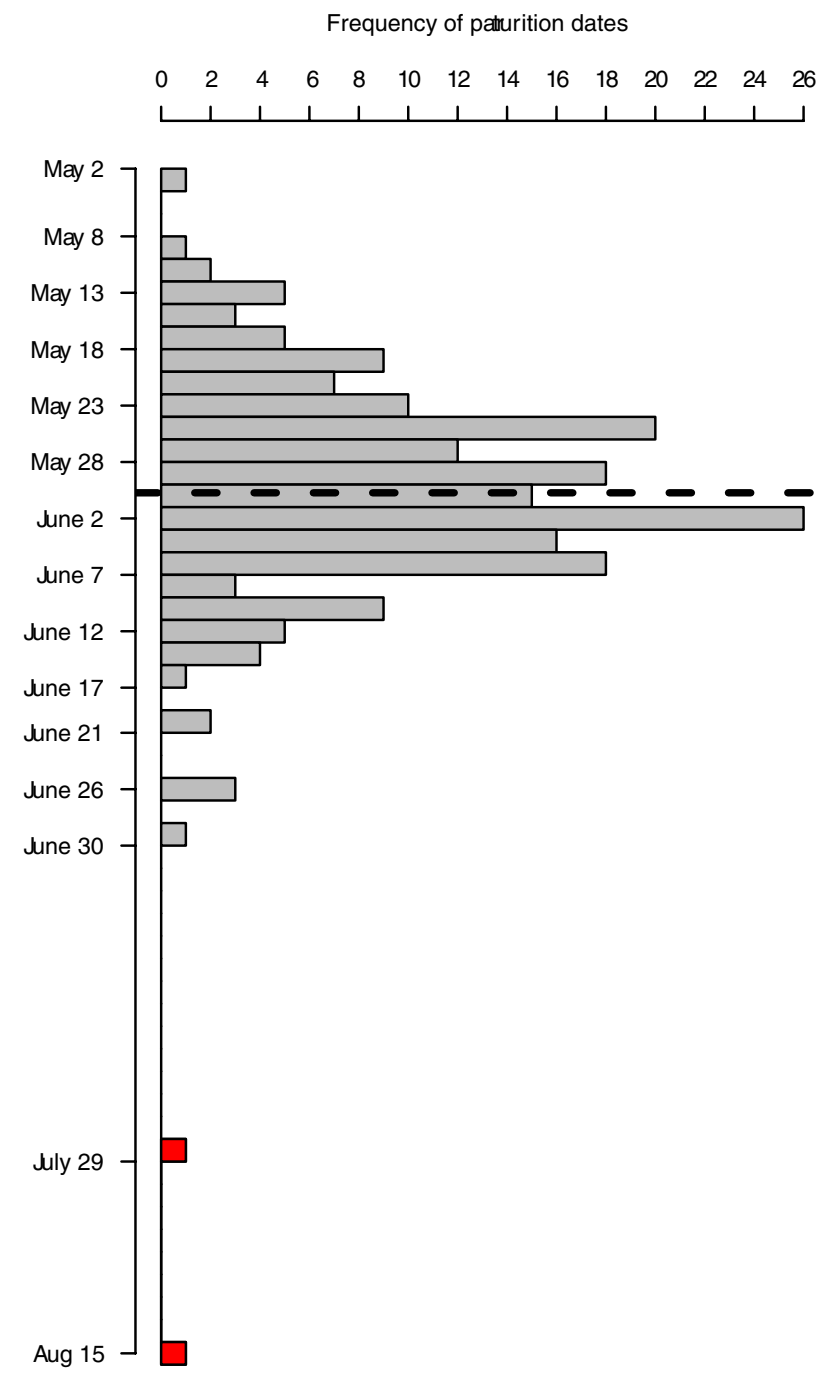

Fig. 2 Distribution of 175 documented parturition dates for wild Eurasian lynx (Lynx lynx) in Scandinavia. Red bars indicated two outliers where female lynx gave birth on July 29th and August 15th. Striped line shows mean birthdate (May 30th) calculated when excluding the two outliers

July 29th and August 15th were a month, or more, later than all other observed dates (the third latest being June 30th) possibly suggesting a second oestrus. A second behavioural oestrus has previously been observed in one captive lynx, 65 days after her first oestrus (Painer et al. 2014). In this case, an ultrasound examination revealed a minor second follicular wave, but the corresponding hormone levels were not indicative of an oestrus and her oestrous behaviour did not reach the same strength as during a proper oestrus (Painer et al. 2014). This captive animal did not have access to any males during this period so it is unknown if the ovulation could have resulted in pregnancy. Breitenmoser-Würsten et al. (2007) report a case of a female lynx who displayed denning behaviour for over 3 weeks (with a normal birth 
date) and then abandoned the site, mated with a male, and gave birth on August 26th indicating that in some cases it is possible for lynx to enter a second oestrus after losing a litter. However, both our females with late births were fitted with GPS-collars and there were no indications in the location data that they had given birth, and lost their kittens, earlier the same summer (although they could have conceived and then aborted). One of the females was monitored intensively during the period as part of a predation study but for the other female it may have gone undetected if she lost a litter very shortly after parturition.

As ovulation can appear spontaneously in lynx, in addition to being induced (Painer et al. 2014), it is crucial for female lynx to have predictable access to males during their period of potential oestrus. We do not know the status of overlapping males for the two females with the latest parturition dates but we do for the female with 4th latest date who gave birth on June 26th (Fig. 2). We have detailed information from two GPS-collared male lynx that interacted with her. The adult male whose home range originally overlapped with the home range of this specific female was killed during a licensed hunting event on February 27 th, i.e. just before the mating season normally starts. The neighbouring male lynx was observed for the first time in her home range on April 7th. The GPS-data further revealed that the new male met with the female for a couple of days around April 17th and most likely mated successfully. This fits well with the known gestation times for the species; 66-70 days (Painer et al. 2014) or 67-72 days (Breitenmoser-Würsten et al. 2007). That the female was in oestrus shortly after the male entered her territory may indicate that the presence of males can potentially induce a second oestrus, which would be a beneficial adaptation in a low density, high turnover, population where alternative mating opportunities may be scarce. However, we cannot know whether she ovulated earlier when no male was present or if she would have spontaneously entered oestrus a second time regardless of the presence of a new male.

One key question is whether late-born kittens can survive until independence and dispersal age. The female lynx giving birth on August 15th was subsequently shot under a livestock-depredation control action together with her male kitten on January 24th the following year. They were both in good condition, as indicated by the amount of internal body fat. The female weighing $18 \mathrm{~kg}$ and the kitten $8 \mathrm{~kg}$. The kitten was smaller than the average $11 \mathrm{~kg}(\mathrm{SD}=1.9)$ for male kittens shot between January 8th and February 28th but within the observed range ( $8 \%$ being under $9 \mathrm{~kg}$; based on 147 dead lynx kittens registered in a national database for carnivores; www.rovbase.no). There was no correlation between date of death and body weight in the "Rovbase" dataset $\left(R^{2}=0.02\right)$. This indicates that the female lynx was able to sustain both herself and her kitten's body condition in spite of giving birth at the end of the summer season. Her home range overlapped with grazing areas of semi-domestic reindeer (Rangifer tarandus) where she most likely could secure enough food (Mattisson et al. 2011; Walton et al. 2017). If female lynx dependent on other prey types also can sustain body condition for herself and her kittens, remains to be seen.

Overall our results show that most wild lynx maintain a highly seasonal birth season due to a single oestrus event, with occasional, but rare late season births stemming from a second oestrus. A second oestrus would minimise the risk of females failing to conceive due to failure to find a mate during the narrow oestrus-window. This would be particularly adaptive in populations with a low density and high turnover (like in Scandinavia; Nilsen et al. 2012a). However, the low frequency of such events implies that it is unlikely to have a significant demographic impact at present. As to whether timing of birth affects the survival or the development of the kittens after independence remains unclear. Overall, there are still many questions about the evolutionary drivers and constrains that have shaped the nature of lynx reproductive physiology and whether second oestrus is an insurance against missing reproduction. The only thing which is clear is that lynx deviates from all other genera of large cats with similar ecology, by being strict seasonal breeders.

Acknowledgements Open Access funding provided by Norwegian institute for nature research. These results have been derived from more than 25 years of lynx research conducted in Norway and Sweden, as part of the large-scale research project Scandlynx (https://scandlynx. nina.no/). The work would not have been possible without help from a large number of fieldworkers and students. We thank them all.

Funding Swedish Environmental Protection Agency, Swedish Research Council for Environment, Agricultural Sciences and Spatial Planning (FORMAS), Norwegian Environment Agency, Research Council of Norway (Grants 251112, 212919, 183176, 165814), county authorities in Hedmark, Oppland, Buskerud, Telemark, Oslo og Akershus, Østfold, Trøndelag, Troms, and Finnmark, Carnivore Management Boards in region 2, 3, 4, 6, 7 and 8, Reindeer Development Fund in Norway, Swedish Association for Hunting and Wildlife, Management, World Wide Fund for Nature (Sweden), and the private foundations "Olle och Signhild Engkvists Stiftelser" and "Marie-Claire Cronstedts Stiftelse".

\section{Compliance with ethical standards}

Conflict of interest The authors declare that they have no conflict of interest.

Open Access This article is licensed under a Creative Commons Attribution 4.0 International License, which permits use, sharing, adaptation, distribution and reproduction in any medium or format, as long as you give appropriate credit to the original author(s) and the source, provide a link to the Creative Commons licence, and indicate if changes were made. The images or other third party material in this article are included in the article's Creative Commons licence, unless indicated 
otherwise in a credit line to the material. If material is not included in the article's Creative Commons licence and your intended use is not permitted by statutory regulation or exceeds the permitted use, you will need to obtain permission directly from the copyright holder. To view a copy of this licence, visit http://creativecommons.org/licenses/by/4.0/.

\section{References}

Andrén H, Linnell JDC, Liberg O, Andersen R, Danell A, Karlsson J, Odden J, Moa PF, Ahlqvist P, Kvam T, Franzen R, Segerström $P$ (2006) Survival rates and causes of mortality in Eurasian lynx (Lynx lynx) in multi-use landscapes. Biol Cons 131:23-32

Arnemo JM, Evans A, Fahlman $\AA$ (2012) Biomedical protocol for freeranging brown bears, gray wolves, wolverines and lynx. https:// www1.nina.no/RovviltPub/pdf/Biomedical\%20Protocols\%20Car nivores\%20March\%202012.pdf. Accessed 10 Mar 2020

Axner E, Uhlhorn H, Ågren E, Mörner T (2009) Reproductive maturation in the male Eurasian Lynx (Lynx lynx): a study on 55 reproductive organs collected from carcasses during 2002-2005. Reprod Domest Anim 44:467-473

Balme GA, Hunter LTB (2013) Why leopards commit infanticide. Anim Behav 86:791-799

Balme GA, Batchelor A, Britz ND, Seymour G, Grover M, Hes L, Macdonald DW, Hunter LTB (2013) Reproductive success of female leopards Panthera pardus: the importance of top-down processes. Mamm Rev 43:221-237

Breitenmoser-Würsten C, Vandel JM, Zimmermann F, Breitenmoser U (2007) Demography of lynx Lynx lynx in the Jura Mountains. Wildl Biol 13:381-392

Chapron G, Kaczensky P, Linnell JDC, von Arx M, Huber D, Andrén H, Lopez-Bao JV, Adamec M, Alvares F, Anders O, Balciauskas L, Balys V, Bedo P, Bego F, Blanco JC, Breitenmoser U, Brøseth H, Bufka L, Bunikyte R, Ciucci P, Dutsov A, Engleder T, Fuxjager C, Groff C, Holmala K, Hoxha B, Iliopoulos Y, Ionescu O, Jeremic J, Jerina K, Kluth G, Knauer F, Kojola I, Kos I, Krofel M, Kubala J, Kunovac S, Kusak J, Kutal M, Liberg O, Majic A, Mannil P, Manz R, Marboutin E, Marucco F, Melovski D, Mersini K, Mertzanis Y, Myslajek RW, Nowak S, Odden J, Ozolins J, Palomero G, Paunovic M, Persson J, Potocnik H, Quenette PY, Rauer G, Reinhardt I, Rigg R, Ryser A, Salvatori V, Skrbinsek T, Stojanov A, Swenson JE, Szemethy L, Trajce A, TsingarskaSedefcheva E, Vana M, Veeroja R, Wabakken P, Wofl M, Wolfl S, Zimmermann F, Zlatanova D, Boitani L (2014) Recovery of large carnivores in Europe's modern human-dominated landscapes. Science 346:1517-1519

Gaillard JM, Nilsen EB, Odden J, Andrén H, Linnell JDC (2014) One size fits all: Eurasian lynx females share a common optimal litter size. J Anim Ecol 83:107-115
Henriksen HB, Andersen R, Hewison AJM, Gaillard JM, Bronndal M, Jonsson S, Linnell JDC, Odden J (2005) Reproductive biology of captive female Eurasian lynx, Lynx lynx. Eur J Wildl Res $51: 151-156$

Jansen BD, Jenks JA (2012) Birth timing for mountain lions (Puma concolor); testing the prey availability hypothesis. PLoS ONE 7:e44625

Logan KA, Sweanor LL (2001) Desert puma: evolutionary ecology and conservation of an enduring carnivore. Island Press, London

Mattisson J, Odden J, Nilsen EB, Linnell JDC, Persson J, Andrén H (2011) Factors affecting Eurasian lynx kill rates on semi-domestic reindeer in northern Scandinavia: can ecological research contribute to the development of a fair compensation system? Biol Cons 144:3009-3017

Nilsen EB, Brøseth H, Odden J, Linnell JDC (2010) The cost of maturing early in a solitary carnivore. Oecologia 164:943-948

Nilsen EB, Brøseth H, Odden J, Linnell JDC (2012a) Quota hunting of Eurasian lynx in Norway: patterns of hunter selection, hunter efficiency and monitoring accuracy. Eur J Wildl Res 58:325-333

Nilsen EB, Linnell JDC, Odden J, Samelius G, Andrén H (2012b) Patterns of variation in reproductive parameters in Eurasian lynx (Lynx lynx). Acta Theriologica 57:217-223

Odden J, Nilsen EB, Linnell JDC (2013) Density of wild prey modulates Lynx kill rates on free-ranging domestic sheep. PLoS ONE 8:e79261

Painer J, Jewgenow K, Dehnhard M, Arnemo JM, Linnell JDC, Odden J, Hildebrandt TB, Goeritz F (2014) Physiologically persistent corpora lutea in Eurasian lynx (Lynx lynx) - longitudinal ultrasound and endocrine examinations intra-vitam. PLoS ONE 9:e90469

Samelius G, Andrén H, Liberg O, Linnell JDC, Odden J, Ahlqvist P, Segerström P, Sköld K (2012) Spatial and temporal variation in natal dispersal by Eurasian lynx in Scandinavia. J Zool 286:120-130

Schmidt K (1998) Maternal behaviour and juvenile dispersal in the Eurasian lynx. Acta Theriol 43:391-408

Walton Z, Mattisson J, Linnell JDC, Stien A, Odden J (2017) The cost of migratory prey: seasonal changes in semi-domestic reindeer distribution influences breeding success of Eurasian lynx in northern Norway. Oikos 126:642-650

Publisher's Note Springer Nature remains neutral with regard to jurisdictional claims in published maps and institutional affiliations. 